\title{
Increasing the Use of E-Learning Platforms in Tertiary Learning Institutions for Blended Distance Programmes in Zambia
}

\author{
Rodgers Himoonga ${ }^{1}$, Jackson Phiri² \\ ${ }^{1}$ Graduate School of Business, University of Zambia, Lusaka, Zambia \\ ${ }^{2}$ Department of Computer Sciences, School of Natural Sciences, University of Zambia, Lusaka, Zambia \\ Email: ^rhimoonga76@yahoo.com, jackson.phiri@cs.unza.zm
}

How to cite this paper: Himoonga, R., \& Phiri, J. (2020). Increasing the Use of ELearning Platforms in Tertiary Learning Institutions for Blended Distance Programmes in Zambia. Open Journal of Social Sciences, 8, 174-190.

https://doi.org/10.4236/jss.2020.88016

Received: June 16, 2020

Accepted: August 18, 2020

Published: August 21, 2020

Copyright $\odot 2020$ by author(s) and Scientific Research Publishing Inc. This work is licensed under the Creative Commons Attribution International License (CC BY 4.0).

http://creativecommons.org/licenses/by/4.0/

(c) (i) Open Access

\begin{abstract}
Zambia embarked on an agenda to attain the vision 2030 which spells that Zambia must reach a middle income status by the year 2030 and highly skilled human capital is necessary for poverty alleviation and enhancement of prosperity. The increase in the use of e-learning platforms in tertiary learning institutions for blended distance programmes is a major boost toward this attainment. The main aim of the study was to increase the use of e-learning platforms in the tertiary learning institutions for blended distance programmes. The objective was to: describe the level to which e-learning platforms have been used by the tertiary learning institutions in Zambia and Prescribe measures that would increase the usage of e-learning platforms in tertiary learning institutions in Zambia. The study was conducted at Evelyn Hone College (EHC), National Institute of Public Administration (NIPA) and Lusaka Business and Technical College (LBTC). The study covered five years time frame from 2015 to 2019 with regard to the environment surrounding e-learning platforms at the three institutions. The research used cross-sectional and mixed methods design. In terms of sampling techniques, the study used Stratified Simple Random Sampling and Purposive or Judgmental Sampling. The quantitative data were collected using two different Likert Scaled questionnaires for both lecturers and students while qualitative data were collected through focus group discussions. The quantitative data were analysed using Stata/SE 12.0 Package for Social Sciences researches and the qualitative data were thematically analysed. The study demonstrated that the levels of use of the e-learning platforms in the three institutions of learning, on overall, were relatively average for lecturers with the following statistics; Evelyn Hone College (EHC) it was $28.89 \%$, Lusaka Business and Technical Colleges (LBTC) it
\end{abstract}


stood at $57.77 \%$ and National Institute of Public Administration (NIPA) it was at $65.31 \%$, while for students on aggregate it was relatively below average and it stood as follows; Evelyn Hone College (EHC) it was 14.52\%, Lusaka Business and Technical College (LBTC) it was at $21.43 \%$, and National Institute of Public Administration (NIPA) it was at $65.83 \%$. In order to boost the utilisation of e-learning platforms, the colleges needed to make the e-learning platforms more user friendly (Ease of use), invest in appropriate hardware and software and alternative sources of power, and consider retraining the e-learning platforms users.

\section{Keywords}

E-Learning, Platforms, Distance Programmes, Zambia

\section{Introduction}

Technology has been appreciated as a basis for competitive advantage for various business sectors. The education sector also has utilised the e-learning technology and has recorded some progress in education accessibility. As of 2015, Zambia Information, Communication and Technology Authority (2015) indicated that out of the ten provinces of Zambia, the population stood at 16 million. Out of this population, 11.6 million of the people had mobile telecommunication tools signifying a $74 \%$ mobile telecommunication penetration rate while the 6.1 million of the population used mobile data which translate into $39 \%$ mobile data usage penetration rate. The 6.1 million of the population which used mobile data were being supported by 38,316 internet service providers nationwide. The above statistics provide evidence that mobile phones and internet had become major channels for education, creativity and self-expression for most of the citizens. However, $30 \%$ of the 6.1 million population who used internet were between the ages of 24 to 35 years. These $30 \%$ of the 6.1 million population translate into 1.83 million of the population of the internet users. Within the 1.83 million of internet users, only $18 \%$ ( 0.33 million) of the internet users used it on educational activities such as research, studying, assessments and others. As such, the main thrust of the study was to increase the use of e-learning platforms in the tertiary learning institutions for blended distance programmes.

\section{Literature Review}

\subsection{Evolution of E-Learning}

The development of the mobile technology brings a new era in e-learning known as mobile-learning. M-learning can be defined as the portable and lightweight platform where the learner can engage in learning activity without having any geographical constraint. Mobile phones, smart phones, palmtops, handheld computers, tablet PCs, laptops and media players aid mobile-learning technique 
(Kukulska-Hulme, 2005). In 1990s, Palm Pilot Personal Digital Assistants (PDAs), a handheld device was developed which performed multi tasks like calculator, calendar and notepad. Modern e-learning methods are considered to be revolutionising contemporary learning systems. But history shows that education can only be developed by evolution and not by revolution (Daniel, 2014).

\subsection{Current State of E-Learning}

The global e-learning market, according to a report developed by the Global Industry Analysts, was estimated to reach US $\$ 107$ billion by 2015 and was expected to rise by $23 \%$ by 2017 (Chuo, Liu, \& Tsai, 2015). The demand for Learning Management System (LMS) would grow from $\$ 2.65$ billion in 2013 to $\$ 7.8$ billion by end of 2018 (Pappas, 2015). Regarding the user base of LMS, Moodle has the highest number of users with 73.8 million; Edomo is second with 58 million followed by Blackboard, having around 20 million users (Pappas, 2015). In 2015 survey, the Chartered Institute of Personnel and Development (CIPD) surveyed the growth of various e-learning methods in organizations. The key findings of the survey are that, there will be 59\% growth in "E-Learning Courses", $40 \%$ in "Blended Learning", and 36\% in "Virtual Classrooms and Webinars", 29\% in "Collaborative and Social Learning", 25\% in "Mobile Based Learning" and 11\% increase in "Gamified Learning" (CIPD, 2015).

\subsection{Distance Learning in Relation to E-Learning}

Distance learning more often than not, incorporates technologies such as the internet; one-way and two-way transmissions through open broadcast, closed circuit, cable, microwave, broadband lines, fibre optics, satellite, or wireless communications devices; audio and video conferencing; or video cassettes, DVDs, and CD-ROMs, in conjunction with any of the other technologies (Clifford \& Pond, 2012).

However, e-learning can either be classified as Asynchronous e-learning or Synchronous e-learning. Firstly, Asynchronous e-learning is a form of self-study that is commonly facilitated by media such as email and discussion groups; supports work relationships among learners with teachers, even when participants cannot be online at the same time. As such, it is a key component of flexible e-learning. On the contrary, synchronous e-learning allows for real-time interaction and just in-time responses between instructors and learners commonly supported by media such as video conferencing and chats. It has a potential to support e-learners in the development of learning-communities (Rym, Olfa, \& Mélika, 2013). The major difference between traditional classroom instruction and distance education is the amount of face-to-face contact students have with an instructor and with other students. Students who are mainly distance learners do have some personal contact with their instructor, but not all contacts happen within the classroom. These students may enroll in a class, be pre-assessed, and receive orientation in the use of the curricula, but then accomplish most of their learning at home or somewhere else outside a classroom. 


\subsection{E-Learning Platforms}

An e-learning platform is a set of interactive online services that provide learners with access to information, tools and resources to support educational delivery and management through the Internet (Ghirardini, 2011).

There are a variety of e-learning platforms with different levels of complexity, but their most common and important features include;

- Learning content management-creation, storage and access to resources;

- Curriculum mapping and planning-lesson planning, personalised learning experience and assessment;

- Learner engagement and management-learner information and progress tracking;

- Tools and services-forums, messaging system, blogs and group discussions.

The colleges under this study used the following two e-learning platforms discussed in the subsequent 2.4.1 and 2.4.2 Sections.

\subsubsection{Astria}

According to Tampa (2018), Astria Learning's origins are rooted in an understanding of the processes and problems that educational institutions face. The innovativeness and customer-centric approach delivered solutions through this platform support the improved delivery and quality of education around the globe. Astria Learning presents several distinct management systems that work seamlessly together to deliver an effective experience for both personnel and students. For example, Astria Learning's Innovative Campus Management System (ACMS) provides an intuitive method of managing students throughout their educational journey. Their Payment Collection System accepts bank transfers, as well as debit and credit cards to make it easier to reach students of all backgrounds. Astria Learning's vibrant and expansive Astria Digital Library makes available over 172,000 e-books as well as millions of articles and journals. All of these robust and timely educational resources can easily be accessed at any time for research purposes or for further reading. This Learning Management System facilitates online distance learning (ODL) and engages students in new and exciting ways to set them up for success in the ever-changing global business and educational environments. Astria Learning also simplifies the process of purchasing educational devices and literature such as tablets and laptops and e-books which are vital to the success of the students' learning.

\subsubsection{Moodle}

Ghirardini (2011) states that Moodle55 is one of the widely used, free of charge and open-source learning platform. It was originally made for education, training and development environments to help educators create online courses with a focus on interaction and collaboration, although lately it has been extended to business settings as well. The platform is used in many countries around the world as it is available in various languages. The latest version of Moodle is 3.0.1. 
Astria and MOODLE are the e-learning platforms being used by the colleges which were sampled in this research. To be specific, Evelyn Hone College and Lusaka Business and Technical College are using Astria while National Institute of Public Administration is using MOODLE. However, there are a number of e-learning platforms available such as; Docebo, eFront, Dokeos and Claroline. Others include; ATutor, ILIAS, OLAT and Saka CLE. All these platforms have common functionalities. Other e-learning platforms with similar features include LRN and Open Elms.

\subsection{E-Learning Related Works}

The related works of a study reveal the researches done in the area of that particular study and identifies the limitations of those researches in relation to the aim of the study in question. In this study, Table 1 brings out its associated works and identifies the limitations of these researches in reference to its aim.

Table 1. Gaps in literature on E-Learning platforms.

\begin{tabular}{|c|c|c|c|}
\hline Title of the Research & $\begin{array}{l}\text { Authors \& } \\
\text { Jurisdiction }\end{array}$ & Key Results & Gap/Critique \\
\hline & & The study results indicated that & The study looked at lecturers' intention \\
\hline Use of Social Media among & Mwalimu, Mulauzi, & Lecturers particularly the younger & to use social media in their lectures by use \\
\hline University of Zambia Lecturers & \& Mwiinga (2018). & ones were leading in using social & of an original TAM \& did not make effort \\
\hline \multirow[t]{2}{*}{ in Teaching and Learning } & Zambia & media platforms for teaching and & to increase the use of the social media \\
\hline & & learning purposes & platforms \\
\hline
\end{tabular}

A Study of the Enablers and Challenges in the Implementation of E-Learning Policies in Technical Education, Vocational and Entrepreneurship Training Colleges in Zambia

The Current State of E-Learning at Universities in Zimbabwe:

Opportunities and Challenges

Comparative Study of Challenges Affecting Adoption of E-Learning for Capacity Building in Public Service Sectors of Kenya and South Africa

Barriers and Strategies on Adoption of E-Learning in Tanzanian Higher Learning Institutions: Lessons for Adopters
Konayuma (2015).

Zambia

Chitanana \&

Madzima (2008).

Zimbabwe

Yegon, Ongus, \& Njuguna (2014) Kenya \& South Africa

Kisanga \& Ireson (2015). Tanzania
The results revealed that the e-learning stakeholders (college managers, lecturers \& students) had different levels of experience and knowledge of e-learning

Results indicated that e-learning at most of the universities was still at its infant stage and faced challenges like lack of infrastructural development, support and pedagogical considerations for e-learning

The study revealed that infrastructure problem, lack of funds and lack of policies favouring the use of e-learning \& provision of reliable e-learning portals to the government employees were hindering e-learning adoption

Highlighted barriers on e-learning adoption include; poor infrastructure; financial constraints; inadequate support; lack of e-learning knowledge and teachers' resistance to change
The study did not seek to increase the implementation of e-learning policies in technical education, vocational and entrepreneurship training colleges

It was an exploration research as opposed to be pragmatic research which could have sought solutions to a low use of e-learning platforms

The study overlooked the need to finding lasting solutions to challenges affecting e-learning

The research just looked at barriers and strategies of adopting e-learning without suggesting ways of increasing the use of e-learning 
From many studies reviewed, it is evident that there has been less effort made by the researchers toward the increase in the use of e-learning platforms in the Zambian educational sector, instead, most of the studies concentrated on assessing the intentions to adopt the electronic systems and challenges of e-learning platforms adoption. This research sought to meet the above gap of the need to increase the use of e-learning platforms in tertiary learning institutions in Zambia as a contribution toward Zambia's vision 2030.

\section{Methodology}

This methodology outlines the Research Design Matrix, targeted populations and their respective sample sizes, sampling techniques and data collection as well as analysis tools used in the study.

\subsection{Research Design Matrix}

The design matrix of a research summarises the key components of the research which encompasses research questions, research objectives, populations and sampling techniques, data collection and analysis instruments. Table 2 presents these components which were applicable to this study.

\subsection{Targeted Populations and Samples Sizes}

The research used a mixed methods paradigm and the sampling frame was composed of populations of lecturers and students from Evelyn Hone College (EHC), National Institute of Public Administration (NIPA) and Lusaka Business and Technical College (LBTC) who were on blended distance programmes. The three colleges were selected as sample colleges based on the fact that they launched e-learning platforms, they are government institutions and they run similar programmes. For quantitative data, the sample sizes from the three institutions for both categories of the targeted populations were calculated using the Yamane Formula given below (Yamane, 1967). The formula takes into consideration the margin of error, the $95 \%$ confidence level, the population and the response distribution (Precision).

The determination of the sample sizes using Yamane (1967) Sample Determination Model were calculated per college per targeted population as follows;

$$
n=\frac{N}{1+N(e)^{2}}
$$

where $n$-required sample size;

$N$-the total population;

$e$-margin of error used was estimated at $5 \%$ or $0.05 \%$.

\section{Calculation of sample sizes for both lecturers and students for Evelyn Hone College (EHC)}

The targeted populations were composed of 61 lecturers and 189 students. Sample Size for lecturers was calculated as follows; 
Table 2. Research design matrix.

\begin{tabular}{|c|c|c|c|c|}
\hline Research Questions & R-Objectives & Population \& Sampling & Data Collection Tools & D-Analysis Tools \\
\hline $\begin{array}{l}\text { What is the level of usage } \\
\text { of e-learning platforms } \\
\text { on blended distance } \\
\text { programmes in tertiary } \\
\text { learning institutions? }\end{array}$ & $\begin{array}{l}\text { To describe the level } \\
\text { to which e-learning } \\
\text { platforms have been used } \\
\text { by the tertiary (colleges) } \\
\text { learning institutions in } \\
\text { Zambia }\end{array}$ & $\begin{array}{l}\text { - Population } 672 \text { of lecturers \& } \\
\text { learners on blended distance } \\
\text { programmes } \\
\text { - Simple random sampling } \\
\text { - Sample sizes per stratum (institution) } \\
\text { per targeted population-Sample sizes, } \\
n=N /\left(1+N(e)^{2}\right) \text { (Yamane, 1967) }\end{array}$ & $\begin{array}{l}\text { Self-administered } \\
\text { questionnaires to- } \\
\text { lecturers \& learners on } \\
\text { distance programmes }\end{array}$ & $\begin{array}{l}\text { - Bivariate analysis- } \\
\text { Chi-Square } \\
\text { - Stata/SE } 12.0 \\
\text { package for social } \\
\text { sciences researches }\end{array}$ \\
\hline $\begin{array}{l}\text { How can the e-learning } \\
\text { platforms use be increased } \\
\text { in tertiary (colleges) } \\
\text { learning institutions? }\end{array}$ & $\begin{array}{l}\text { To recommend } \\
\text { possible solution that } \\
\text { would increase the usage } \\
\text { of e-learning platforms in } \\
\text { tertiary (colleges) } \\
\text { learning institutions }\end{array}$ & $\begin{array}{l}\text { - Population of stake-holders-lecturers } \\
\text { \& managers on blended distance } \\
\text { programmes } \\
\text { - Non-randomised expert sampling- } \\
\text { Purposive Sampling } \\
\text { - Sample size-small \& subjective to the } \\
\text { researcher's judgement \& maximum } \\
\text { variation per institution }\end{array}$ & $\begin{array}{l}\text { Workshops composed } \\
\text { of-lecturers \& managers } \\
\text { on blended distance } \\
\text { programmes }\end{array}$ & $\begin{array}{l}\text { - Content analysis. } \\
\text { - Thematic analysis }\end{array}$ \\
\hline
\end{tabular}

\section{Data:}

Population $(N)=61$

Margin of error $(e)=0.05$

Sample size $(n)=$ ?

\section{Calculation:}

$n=61 / 1+61(0.05)^{2}=61 / 1+61(0.0025)=61 / 1+0.1525=61 / 1.1525=\underline{\mathbf{5 3}}$

Sample size for students was calculated as follows;

Data:

Population $(N)=189$

Margin of error $(e)=0.05$

Sample size $(n)=$ ?

\section{Calculation:}

$n=189 / 1+189(0.05)^{2}=189 / 1+189(0.0025)=189 / 1+0.4725=189 / 1.4725=$

$\underline{128}$

Calculation of sample sizes for both lecturers and students for National Institute of Public Administration (NIPA)

The targeted populations were 80 lecturers and 247 students.

Sample Size for lecturers was calculated as follows;

\section{Data:}

Population $(N)=80$

Margin of error $(e)=0.05$

Sample size $(n)=$ ?

\section{Calculation:}

$n=80 / 1+80(0.05)^{2}=80 / 1+80(0.0025)=80 / 1+0.2=80 / 1.2=\underline{67}$

Sample size for students was calculated as follows;

Data:

Population $(N)=247$

Margin of error $(e)=0.05$ 
Sample size $(n)=$ ?

\section{Calculation:}

$n=247 / 1+247(0.05)^{2}=247 / 1+247(0.0025)=247 / 1+0.6175=247 / 1.6175$

$=\underline{153}$

Calculation of sample sizes for both lecturers and students for Lusaka Business and Technical College (LBTC)

The targeted populations were made of 65 lecturers and 30 students.

Sample size for lecturers was calculated as follows;

Data:

Population $(N)=65$

Margin of error $(e)=0.05$

Sample size $(n)=$ ?

Calculation:

$n=65 / 1+65(0.05)^{2}=65 / 1+65(0.0025)=65 / 1+0.1625=65 / 1.1625=\underline{\mathbf{5 6}}$

Sample size for students was calculated as follows;

Data:

Population $(\mathrm{N})=30$

Margin of error $(e)=0.05$

Sample size $(n)=$ ?

\section{Calculation:}

$n=30 / 1+30(0.05)^{2}=30 / 1+30(0.0025)=30 / 1+0.075=30 / 1.075=\underline{\mathbf{2 8}}$

Table 3 presents a summary of the above calculated sample sizes for both lecturers and students for each college.

While Table 4 gives a summary of the total targeted populations from the three institutions and their associated total sampled elements from the three institutions.

The researcher used the formula devised by Yamane (1967) because it can generate a sample size for any size of the population which could be an even or odd number though it uses a fixed margin of error which is $5 \%$. The sample sizes for qualitative data were subject to the researcher since he used non-probability sampling.

Table 3. Targeted populations, sample sizes and response rates per respondents' category per college.

\begin{tabular}{|c|c|c|c|c|c|c|}
\hline & \multicolumn{6}{|c|}{ On Blended Distance Programmes } \\
\hline & \multicolumn{2}{|c|}{$\mathrm{EHC}$} & \multicolumn{2}{|c|}{ NIPA } & \multicolumn{2}{|c|}{ LBTC } \\
\hline Parameter & Lecturers & Students & Lecturers & Students & Lecturers & Students \\
\hline Targeted population per college & 61 & 189 & 80 & 247 & 65 & 30 \\
\hline Calculated sample sizes & 53 & 128 & 67 & 153 & 56 & 28 \\
\hline N0 of questionnaire responded to & 45 & 126 & 49 & 120 & 45 & 28 \\
\hline Response rates & $84.9 \%$ & $98.4 \%$ & $73.1 \%$ & $78.4 \%$ & $80.4 \%$ & $100 \%$ \\
\hline
\end{tabular}


Table 4. Total targeted populations and aggregated sample sizes.

\begin{tabular}{llll}
\hline & \multicolumn{3}{l}{ On Blended Distance Programmes } \\
\hline Parameter & Lecturers & Students & Total \\
\hline The total targeted population from the three colleges & 206 & 466 & 672 \\
$\begin{array}{l}\text { The total sampled elements from the three colleges as } \\
\text { calculated above }\end{array}$ & 176 & 309 & 485 \\
$\begin{array}{l}\text { Total No. of questionnaires responded to \& returned } \\
\text { to the researcher }\end{array}$ & 139 & 274 & 413 \\
\hline
\end{tabular}

In terms of sampling techniques, the study used two techniques, namely; Stratified Simple Random Sampling and Purposive or Judgmental Sampling. Each of the colleges was treated as a stratum

The quantitative data was collected using two different Likert Scaled Questionnaires for both lecturers and students. The use of questionnaires in this study was informed by many past similar researches which employed the same tool such as Akour \& Dwairi (2012), Al-Aulamie (2013), Phatthana (2011), Mathieson, Peacock, \& Chin (2015), and Soneka \& Phiri (2019) just to mention but a few.

In addition, the validity and reliability of the questionnaire was assured. Firstly, validity is the strength of the conclusions, inferences or propositions made from the outcomes of the used instrument. Put differently, it is the best available approximation to the truth or falsity of a given inference, proposition or conclusion, whereas reliability of a research instrument is viewed to be its consistency, or the degree to which an instrument measures the same way each time it is used under the same condition with the same subjects. A measure is considered reliable if a subject's score on the same test given twice is similar (Retrieved from http://www.socialresearchmethods.net/tutorial/Colosi/lcolosi2.htm).

Validity has many dimensions, among key ones there is; Face Validity, Content Validity, Construct Validity and Criterion Validity. In terms of Face Validity, this research's questionnaires had an attachment of an introductory letter which assured the respondents of total adherence to research ethics and the questionnaires format was Likert scaled of strongly agree, agree, neutral, disagree and strongly disagree to the statements of the questions. On the areas of Content and Construct Validities, the questionnaires covered the core theme (level to which e-learning platforms have been used) of the first research question (what is the level of usage of e-learning platforms on blended distance programmes in tertiary learning institutions?) by operationalising this question as follows;

\begin{tabular}{cccccc}
\hline E-learning Use & \multicolumn{4}{c}{ (Tick $\sqrt{ }$ where applicable) } \\
\hline $\begin{array}{c}\text { A proxy statement used for } \\
\text { e-learning platform usage }\end{array}$ & $\begin{array}{c}\text { Strongly } \\
\text { agree }\end{array}$ & Agree & Neutral & Disagree & $\begin{array}{c}\text { Strongly } \\
\text { disagree }\end{array}$ \\
\hline I frequently use the e-learning platform & & & & & \\
\hline
\end{tabular}


The above operationalisation was also compared with the Likert questionnaire used by Soneka \& Phiri (2019) who did a similar research titled A Model for Improving E-Tax Systems Adoption in Rural Zambia Based on the TAM Model under Zambia Revenue Authority.

Reliability can be measured mostly either by the procedure of Test-retest or Consistency (Soneka \& Phiri, 2019). The researcher used the former procedure. A total number of 13 and 14 lecturers were randomly selected from Evelyn Hone College and Lusaka Business and Technical College respectively, and a total of 32 and 7 students were also randomly sampled from Evelyn Hone College and Lusaka Business and Technical College in that order who were on blended distance programmes but these students were finalists in their respective programmes. The students who participated in the questionnaire test-run did not take part in the actual study. The first questionnaire test-run was done in April 2019. After the analysis of the collected data in the first questionnaires' test-run, some minor refinement of the questionnaires was made. The re-testing of the questionnaires was done in May 2019 using the same lecturers and students who participated in the first questionnaire test run. Although the lecturers and students were from different environments or colleges and under different programmes, and tests being done at different times, the obtained $P$ values from the two pilot tests were similar. Finally, the reliability of the data collection instrument was re-enforced by the use of Yamane Model in determining the samples sizes.

The actual data collection for the research was done in August/September 2019 during the residential school for the blended distance programmes at the three institutions.

The qualitative data for the second Research Question were obtained using Purposive Sampling technique through focus group discussions and a discussion guide was employed in guiding the researcher during the discussions.

Table 5 presents an array of characteristics of the discussants who took part in focus groups discussions for the research. These characteristics include sex, education and the positions held by the discussants. The presented characteristics attest to the fact that the researcher achieved the maximum variation of the respondents under qualitative data.

\subsection{Data Analysis}

The collected quantitative data were compiled, summarised and analysed using Stata/SE 12.0 Package for Social Sciences researches. Stata/SE 12.0 Package for Social Sciences researches was used due to its user friendliness in that it is easy to compute frequencies and present the computed data in different graphical forms such as frequency tables, histograms, pie charts, and so on. Qualitative data were analysed by grouping the responses into common themes, coded and then analysed thematically.

\section{Results}

The total respondents were 672 for quantitative data while for qualitative data 
they were 13 . Among the 672 respondents, 206 were lecturers signifying $30.65 \%$ while 466 were students representing 69.35\%. Among the 206 lecturers, 34\% were in 30 - 39 years of age bracket while $27 \%$ were in 40 - 49 years of age range, $19 \%$ were between 50 and 59 years of age and $20 \%$ were above the age of 59 years. For students, $52 \%$ of 466 were between 20 and 29 years of age, $41 \%$ were in the class of $30-39$ years of age and $7 \%$ were above the age of 39 years. In terms of their highest educational attainment, $65 \%$ of lecturers had degrees, $30 \%$ had masters, $4 \%$ had had diplomas and $1 \%$ had PhDs. The students' highest educational attainment stood at $46 \%$ had certificates, $28 \%$ had diplomas, $11 \%$ degrees, $1 \%$ had masters and $14 \%$ had unclassified qualifications. In terms of sex, $32 \%$ were females while $68 \%$ were males for lecturers. For students, $48 \%$ were females and $52 \%$ were males. For the 13 discussants used for focus group discussions from the three colleges, see Table 5 for their demographic data.

Table 5. Sample sizes \& demographic characteristics of sample elements of qualitative data.

\begin{tabular}{llll}
\hline & \multicolumn{3}{c}{ Strata-Colleges } \\
\cline { 2 - 3 } $\begin{array}{l}\text { Background information of Focus } \\
\text { Groups Discussants }\end{array}$ & $\begin{array}{l}\text { Evelyn Hone } \\
\text { College }\end{array}$ & $\begin{array}{l}\text { National Institute of } \\
\text { Public Administration Technical College }\end{array}$ & Lusaka Business \& \\
\hline
\end{tabular}

1) Sex of the discussants

Number of Males from each college

Number of Females from each college

Total number of discussants

2) Highest level of education attained

Number of discussants with

Diplomas

Number of discussants with

Degrees

Number of discussants with

Masters

Number of discussants with $\mathrm{PhDs}$

Total number of discussants

3) Position held

Number of discussants who were heads of blended distance programmes

Number of discussants who were information technology specialist

Number of discussants who were lecturers

Total number of discussants
2

2

4

1

0

1

2

1

2

2

3

1

4

0

0

5

1

1

1

$2 \quad 2$

4 


\section{Description of the Levels to Which E-Learning Platforms Have Been Used}

In response to the first objective, Table 6 and Table 7 give detailed descriptions of the levels of usage of e-learning platforms at the three tertiary learning institutions in terms of frequencies and percentages for lecturers and students respectively. The statement "I frequently use the e-learning platform" was used as a proxy for a lecturer or student using an e-learning platform in this study.

The usage of e-learning platforms is signified by agreeing and strongly agreeing that a lecturer frequently uses the e-learning platform. It is seen from Table 6 that the levels of usage of e-learning platforms are different across the three colleges among lecturers as indicated by the $P$ value $(0.000)$. Over all, when the two levels of agreements (Agree \& Strongly Agree) are combined, the levels of usage of e-learning platforms among lecturers stood as follows; Evelyn Hone College (EHC), 28.89\%, Lusaka Business and Technical Colleges (LBTC), 57.77\% and National Institute of Public Administration (NIPA) was $65.31 \%$. On aggregate, the usage of e-learning platforms among lecturers was relatively average.

Table 6. Lecturers' perception on their usage of e-learning platform by institutions.

\begin{tabular}{|c|c|c|c|c|c|c|c|}
\hline \multirow{2}{*}{\multicolumn{2}{|c|}{ Institution }} & \multicolumn{6}{|c|}{ I frequently use the e-learning platform } \\
\hline & & \multirow{2}{*}{$\begin{array}{c}\text { Strongly Agree } \\
1\end{array}$} & \multirow{2}{*}{$\begin{array}{c}\text { Agree } \\
12\end{array}$} & \multirow{2}{*}{$\begin{array}{c}\text { Neutral } \\
10\end{array}$} & \multirow{2}{*}{$\begin{array}{c}\text { Disagree } \\
14\end{array}$} & \multirow{2}{*}{$\begin{array}{c}\text { Strongly Disagree } \\
8\end{array}$} & \multirow{2}{*}{$\begin{array}{c}\text { Total } \\
45\end{array}$} \\
\hline $\mathrm{EHC}$ & Frequency & & & & & & \\
\hline БП & $\%$ & 2.22 & 26.67 & 22.22 & 31.11 & 17.78 & 100.00 \\
\hline \multirow{2}{*}{ LBTC } & Frequency & 2 & 24 & 9 & 10 & 0 & 45 \\
\hline & $\%$ & 4.44 & 53.33 & 20.00 & 22.22 & 0.00 & 100.00 \\
\hline \multirow{2}{*}{ NIPA } & Frequency & 0 & 32 & 14 & 3 & 0 & 49 \\
\hline & $\%$ & 0.00 & 65.31 & 28.57 & 6.12 & 0.00 & 100.00 \\
\hline \multirow{2}{*}{ Total } & Frequency & 3 & 68 & 33 & 27 & 8 & 139 \\
\hline & $\%$ & 2.16 & 48.92 & 23.74 & 19.42 & 5.76 & 100.00 \\
\hline \multicolumn{2}{|c|}{ Chi-Square Test } & \multicolumn{2}{|l|}{ Value } & \multicolumn{2}{|c|}{ d.f. } & \multicolumn{2}{|c|}{ Asymp. Sig. (2-Sided) } \\
\hline \multicolumn{2}{|c|}{ Pearson Chi-Square } & \multicolumn{2}{|l|}{34.8826} & \multicolumn{2}{|c|}{8} & \multicolumn{2}{|l|}{0.000} \\
\hline
\end{tabular}

Table 7. Students' perception on their usage of e-learning platform by institutions.

\begin{tabular}{|c|c|c|c|c|c|c|c|}
\hline \multirow{2}{*}{\multicolumn{2}{|c|}{ Institution }} & \multicolumn{6}{|c|}{ I frequently use the e-learning platform } \\
\hline & & Strongly Agree & Agree & Neutral & Disagree & Strongly Disagree & Total \\
\hline \multirow{2}{*}{ EHC } & Frequency & 1 & 17 & 42 & 64 & 0 & 124 \\
\hline & $\%$ & 0.81 & 13.71 & 33.87 & 51.61 & 0.00 & 100.00 \\
\hline \multirow{2}{*}{ LBTC } & Frequency & 2 & 4 & 7 & 14 & 1 & 28 \\
\hline & $\%$ & 7.14 & 14.29 & 25.00 & 50.00 & 3.57 & 100.00 \\
\hline \multirow{2}{*}{ NIPA } & Frequency & 1 & 78 & 39 & 2 & 0 & 120 \\
\hline & $\%$ & 0.83 & 65.00 & 32.50 & 1.67 & 0.00 & 100.00 \\
\hline \multirow{2}{*}{ Total } & Frequency & 4 & 99 & 88 & 80 & 1 & 272 \\
\hline & $\%$ & 1.47 & 36.40 & 32.35 & 29.41 & 0.37 & 100.00 \\
\hline \multicolumn{2}{|c|}{ Chi-Square Test } & \multicolumn{2}{|l|}{ Value } & \multicolumn{2}{|c|}{ d.f. } & \multicolumn{2}{|c|}{ Asymp. Sig. (2-Sided) } \\
\hline \multicolumn{2}{|c|}{ Pearson Chi-Square } & \multicolumn{2}{|l|}{120.5940} & \multicolumn{2}{|c|}{8} & \multicolumn{2}{|l|}{0.000} \\
\hline
\end{tabular}


The usage of e-learning platforms for students is also denoted by agreeing and strongly agreeing that a student frequently uses the e-learning platform. It is seen from Table 7 as well that the levels of usage of e-learning platforms are different across colleges among students as shown by the $P$ value $(0.000)$ which is below $5 \%$ of the level of significance. Similarly, when the two extents of agreements (Agree \& Strongly Agree) are put together, the levels of utilisation of e-learning platforms among the students stood as follows; Evelyn Hone College (EHC), 14.52\%, Lusaka Business and Technical Colleges (LBTC), 21.43\% and National Institute of Public Administration (NIPA) was $65.83 \%$. Over all, the usage of e-learning platforms among students was below average.

\section{Discussion}

The research aimed at increasing the use of e-learning platforms in the tertiary learning institutions for blended distance programmes in Zambia. The levels of usage of e-learning platforms across colleges are different among lecturers with Evelyn Hone College (EHC), 28.89\%, Lusaka Business and Technical Colleges (LBTC), $57.77 \%$ and National Institute of Public Administration (NIPA) was $65.31 \%$. For students, it was different as well with Evelyn Hone College (EHC), 14.52\%, Lusaka Business and Technical Colleges (LBTC), 21.43\% and National Institute of Public Administration (NIPA) was $65.83 \%$. Konayuma (2015) conducted a study with the subject title "Enablers and Challenges in the Implementation of E-learning Polices in Technical Education, Vocational and Entrepreneurship Training Colleges in Zambia", the results of his study also revealed that the e-learning stakeholders (college managers, lecturers \& students) had different levels of experiences and knowledge of e-learning.

In addition, Goodhue \& Thompon (1995) presented precursors of utilisation of an electronic system which included beliefs (perceptions) of using an electronic system. Elkaseh, Wong, \& Fung (2015) in their study titled "The Acceptance of E-learning as a Tool for Teaching and Learning in Libyan Higher Education", found that perceived enjoyment has a significant direct effect on perceived ease of use both for teachers \& learners.

The levels of usage of the e-learning platforms by the colleges can also be explained by some of the challenges they may be facing in increasing the usage of e-learning platforms. In a study titled "Barriers and Strategies on Adoption of E-Learning in Tanzanian Higher Learning Institutions. Lessons for Adopters", done by Kisanga \& Ireson (2015) in Tanzania, the findings highlighted that barriers on e-learning adoption such as; poor infrastructure, financial constraints, inadequate support, lack of e-learning knowledge and teachers' resistance to change account for non-adoption of e-learning platforms.

\section{Conclusion}

The main thrust of the study was to increase the use of e-learning platforms in the tertiary learning institutions for blended distance programmes. The objec- 
tives were to describe the level to which e-learning platforms have been used by the tertiary learning institutions in Zambia and give measures that would increase the usage of e-learning platforms. The study was conducted at Evelyn Hone College, National Institute of Public Administration, and Lusaka Business and Technical Colleges in 2019. The research used cross-sectional and mixed methods design while the sampling techniques used include Stratified Simple Random Sampling and Purposive or Judgmental Sampling. The quantitative data were collected using two different Likert scaled questionnaires for lecturers and students while qualitative data were collected using focus group discussions. The quantitative data were analysed using Stata/SE 12.0 Package for social sciences researches while qualitative data were analysed using thematic and content analyses.

The results of the study showed different levels of usage of the e-learning platforms in the three institutions among lecturers and students. However, on overall, the use e-learning platforms was relatively on average among lecturers with the following scores; Evelyn Hone College (EHC) it stood at $28.89 \%$ while Lusaka Business and Technical College (LBTC) it was $57.77 \%$ and National Institute of Public Administration (NIPA) it was at $65.31 \%$. For students on overall picture, it was relatively below average with the following percentages; Evelyn Hone College (EHC) it was $14.52 \%$, Lusaka Business and Technical College (LBTC) it was at $21.43 \%$, and National Institute of Public Administration (NIPA) it was at $65.83 \%$.

As a way of increasing the use of e-learning platforms, colleges needed to make e-learning platforms more user friendly, invest in ideal information, communication and technology hardware and software and alternative sources of power, and consider well-planned training and the retraining of the e-learning platforms users.

Like many a research, this particular study also encountered a set of limitations. Limitations of the research refer to a set of factors related to the structure of the methodology that has a bearing on the data collection, analysis and interpretation of the findings (Roggema, 2014). Sampling techniques used include stratified simple random sampling and non-probability sampling (purposive sampling). Stratified simple random sampling technique may have an inherent data quality challenges in line with quantitative researches (Saunders, 2012). This technique is blind to the quality of the sampled items. Therefore it can lead to misapplication of the results, and challenges in getting in-depth information; data collected may not be factual and may have weaknesses of inaccuracies. The purposive sampling technique is also susceptible to; a researcher's biased selection of discussants that can be convenient for him/her which may lead to misrepresenting the sampling frame (population). Samples based on the researcher's judgment may be practical to him/her; however, they may have systematic embedded errors that can twist the orientation of the research's results (Queirós, Faria, \& Almeida, 2017). While the researcher used maximum characteristics 
variation in selecting sample items for non-probability sampling, see Table 5, the technique may not satisfy the tests of adequacy in terms of quantity and representativeness of populations' characteristics. As such, the results of such a study will have a limitation as far as generalisability principle is concerned.

This study also presents an opportunity for another research to be carried out so that an appreciable in-depth understanding on the topic can be gained. A study needs to be done on, assessing the applicability of e-learning platforms on practical programmes which require experiments, such as Science, Agricultural or Electronic related programmes within the Zambian educational environment. A mixed method study strategy can still be applied for such a research.

\section{Recommendations}

In accordance with this research's findings and the identified gaps in its reviewed literature, the following recommendations are made based also on the second objective. The researcher therefore recommends that the e-learning platforms be revised and be improved to make them more user friendly and effective. There is also need to invest in appropriate hardware and software of information, communication and technologies. The colleges also need to invest in alternative sources of power such as diesel or petrol powered generator sets and solar power in order to counter the load-shedding by the electricity utility supply company. Additionally, the institutions may as well consider retraining e-learning platforms users to enable them gain knowledge and the skill of using e-learning platform. Finally prior to these trainings, the users need to fully appreciate the purposes and benefits (usefulness) of e-learning platforms so that they can own the platforms and use them as their personal academic tools.

\section{Acknowledgements}

The authors would like to recognise the valuable help of everyone who supported in the distribution and responding to questionnaires and those who participated in focus group discussions.

\section{Conflicts of Interest}

The authors declare no conflicts of interest regarding the publication of this paper.

\section{References}

Akour, I. A., \& Dwairi, M. A. (2012). Testing Technology Acceptance Model in Developing Countries: The Case of Jordan. International Journal of Business and Social Science, 2, 278-284.

Al-Aulamie, A. (2013). Enhanced Technology Acceptance Model to Explain and Predict Learners Behavioural Intentions in Learning Management. Bedfordshire: University of Bedfordshire.

Chitanana, L., \& Madzima, D. M. K. (2008). The Current State of E-Learning at Universities in Zimbabwe: Opportunities and Challenges. International Journal of Education 
and Development using Information and Communication Technology, 4, 5-15.

Chuo, Y., Liu, C., \& Tsai, C. (2015). Effectiveness of E-Learning in Hospitals. Technology and Health Care, 23, S157-S160. https://doi.org/10.3233/thc-150949

CIPD (2015). Learning and Development. London: Chartered Institute of Personnel and Development CIPD.

Clifford, S., \& Pond, J. (2012). Quality Distance Education Program Webinar California Community College System.

Daniel, S. J. (2014). Open, Distance and Online Learning: A Brief History. In International Conference on Emerging Technologies in Education and Computer Science (pp. 87-94). Lisbon: IADIS Press.

Elkaseh, A. M., Wong, K. W., \& Fung, C. C. (2015). The Acceptance of E-Learning as a Tool for Teaching and Learning in Libyan Higher Education. International Journal of Information Technology, 3, 1.

Ghirardini, B. (2011). E-Learning Methodologies: A Guide for Designing and Developing E-Learning Courses.

Goodhue, D. L., \& Thompon, R. L. (1995). Task-Technology Fit and Individual Performance. MIS Quarterly, 19, 213-236. https://doi.org/10.2307/249689 http://www.socialresearchmethods.net/tutorial/Colosi/lcolosi2.htm

Kisanga, D., \& Ireson, G. (2015). Barriers and Strategies on Adoption of E-Learning in Tanzanian Higher Learning Institutions: Lessons for Adopters. International Journal of Education and Development Using Information and Communication Technology, 11, 126.

Konayuma, G. S. (2015). A Study of the Enablers and Challenges in the Implementation of E-Learning Policies in Technical Education, Vocational and Entrepreneurship Training Colleges in Zambia.

Kukulska-Hulme, A. (2005). Mobile Learning: A Handbook for Educators and Trainers. London \& New York: Routledge.

Mathieson, K., Peacock, E., \& Chin, W. W. (2015). Extending the Technology Acceptance Model: The Influence of Perceived User Resources.

Mwalimu, E. C., Mulauzi, F., \& Mwiinga, T. M. (2018). Use of Social Media among University of Zambia Lecturers in Teaching and Learning.

Pappas, C. (2015). The Top LMS Statistics and Facts for 2015 You Need to Know. http://elearningindustry.com/top-lms-statistics-and-facts-for-2015

Phatthana, W. (2011). The Application of Technology Acceptance Model 2 (TAM 2) e-Purchase Intention among Health Tourist in Thailand.

Queirós, A., Faria, D., \& Almeida, F. (2017). Strengths and Limitations of Qualitative and Quantitative Research Methods. European Journal of Education Studies, 3, 369-387.

Roggema, R. (2014). Introduction, Methodology, Limitations. In Swarm Planning (pp. 1-30). Berlin: Springer. https://doi.org/10.1007/978-94-007-7152-9_1

Rym, B., Olfa, B., \& Mélika, B. M. B. (2013). Determinants of E-Learning Acceptance: An Empirical Study in the Tunisian Context. American Journal of Industrial and Business Management, 3, 307-321. http://www.scirp.org/journal/ajibm https://doi.org/10.4236/ajibm.2013.33036

Saunders, M. L. (2012). Research Methods for Business Students (6th ed.). Harlow: Pearson Education Limited.

Soneka, P. N., \& Phiri, J. (2019). A Model for Improving e-Tax Systems Adoption in Rural Zambia Based on the TAM Model. Open Journal of Business and Management, 7, 
908-918. https://doi.org/10.4236/ojbm.2019.72062

Tampa, F. (2018). The Copperbelt University (CBU) Memorandum of Agreement (MOA).

Yamane, T. (1967). Statistics: An Introductory Analysis (2nd ed.). New York: Harper and Row.

Yegon, K., Ongus, R., \& Njuguna, A. (2014). Comparative Study of Challenges Affecting Adoption of E-Learning for Capacity Building in Public Service Sectors of Kenya and South Africa. http://www.hrpub.org

Zambia Information, Communication and Technology Authority (2015). ICT Survey Report-Households and Individuals: Survey on Access and Usage of Information and Communication Technology by Households and Individuals in Zambia.

https://www.zicta.zm/Views/Publications/2015ICTSURVEYREPORT 